CESIS Electronic Working Paper Series

Paper No. 301

\title{
Banks and New Firm Formation
}

\author{
Mikaela Backman
}

March, 2013 


\title{
Banks and New Firm Formation
}

\author{
Mikaela Backman \\ Jönköping International Business School \\ P. O. Box 1026 \\ SE-551 11 Jönköping, Sweden \\ Telephone: +46 (0) 36101746 \\ Fax: +46 (0) 36121832 \\ mikaela.backman@jibs.hj.se
}

\begin{abstract}
It is natural to assume that the characteristics of the bank sector are important factors for new firm formation when external capital is needed for establishing new firms. The local bank sector acts as the main provider of financial funds in Sweden since other sources of external capital are limited. In addition, the banking services needed in the start-up process tend to be sensitive to distance and are mainly supplied locally. Thus, the structure of the local bank sector is an important factor that determines the conditions for start-ups. The finding in this paper supports the hypothesis that new firm formation is positively influenced by (1) the average size of the bank branches, (2) number of independent banks and bank branches per capita, and (3) the intensity of competition level. Access to independent banks and bank branches has a stronger influence on start-ups in more rural locations.
\end{abstract}

Keywords: new firm formation, local bank sector, competition, Sweden

JEL classification codes: G21, L26, R11 


\section{Introduction}

Start-ups contribute to employment growth, productivity growth, new innovations, and generate conditions that are favorable for most firms (van Praag and Versloot, 2007). It is therefore important to identify what factors that influence new firm formation and that are relevant for policy discussions and decisions. There is an extensive literature examining regional characteristics that influence the rate of start-ups (Davidsson et al., 1994; Armington and Acs, 2002; Sutaria and Hicks, 2004; Nyström, 2006). The importance of available financial capital in determining new firm formation rate is emphasized in previous studies, confirming the importance of financial intermediaries for creating favorable conditions for new firm formation (Evans and Jovanovic, 1989; Winker, 1999; Andersson et al., 2001; Bonaccorsi di Patti and Dell'Ariccia, 2004; Parker, 2004; Sutaria and Hicks, 2004; Colombo and Grilli, 2006; Tucker, 2006). Few studies have explicitly focused on the local bank market. Against this background, the purpose of this paper is to analyse how the characteristics of the local bank sector influence new firm formation. The analysis is conducted at the local level, since the market for bank loans to a high extent is local (Berger et al., 1999; Kwast, 1999; Collender and Shaffer, 2003). The present paper gives a nuanced picture of the local bank sector and increases the knowledge concerning what characteristics of the local bank sector that influence new firm formation.

A firm founder is forced to seek external capital if informal capital, i.e. capital from the firm founder, friends, or family is limited. New technology and online bank services reduce the importance of physical distance for some bank activities. Proximity still matters for new firm formation in the quest for external finance since face-to-face contacts are central in the coordination process and when applying for loans (Petersen and Rajan, 2002; Storper and Venables, 2004). The importance of banks is particularly great in Sweden since the financial system is bank-oriented and founded on relationships between banks and their customers. In addition, other funds play a limited role in the allocation of financial means to support startups. ${ }^{i}$ In this context, the role of the bank system is of great importance in financing firms both at the start-up and the growth stage (Sjögren and Zackrisson, 2005). Based on the above arguments, one can assume that access to local banks is critical for the start-up of firms. 
Most bank branches in Sweden are subsidiaries of large bank corporations and consequently the available amount of financial funds should in theory not be a binding constraint. Even so, in some municipalities in Sweden there are signs of insufficient supply of financial funds for start-ups (Blanchflower et al., 2001; Nykvist, 2008). This implies that there may be other factors influencing the access to capital in business creation. This paper shows a positive relationship between the average size of bank branches, independent banks and bank branches per capita and the number of start-ups in Swedish municipalities. Furthermore, the results show that an increased competition level measured through employment in bank branches is positively associated with the rate of new firms. This implies that the local bank sector in terms of level of competition, size of bank branches, and the number of possible loan providers is of importance for new firm formation. A somewhat different pattern evolves when the sample is divided into one rural category and one urban category. Access to independent banks and bank branches tends to be more important in a rural setting.

The remainder of this paper is organized as follows: the next section portrays the banking sector in Sweden. Section 3 presents the theoretical framework discussing how the bank sector influences new firm formation. Data and the methodology are presented in Section 4, followed by the empirical analysis in Section 5. Section 6 concludes the paper.

\section{Banking sector}

The institutional setting in a country naturally influences the rate of firm formation. Henrekson (2005) finds that the institutional settings of a mature welfare state such as Sweden discourage both opportunity and necessity based firm creation. Hampering effects include both tax and welfare arrangements, high bureaucratic costs and the fact that individuals who become insolvent are punished by a complex bankruptcy process (Bosma et al., 2007).ii Another reason for the low start-up rate is the industrial structure with disproportionally many large firms that tend to reduce the rate of formation of firms (Davis and Henrekson, 1997; Pagano and Schivardi, 2003; Parker, 2004).

Banks play an important role in Sweden since they provide financing in all phases of a firm's life-cycle. A large share of firms hold bank loans irrespective of size and location (Sjögren and Zackrisson, 2005; Berggren 
and Silver, 2010). The dependence of bank, size of financial markets, and number of bank relationships are features that Sweden share with other developed countries such as Germany, Japan, the Netherlands, and United Kingdom (Ongena and Smith, 2000; Demirguc-Kunt and Levine, 2004).

In the work by Demirguc-Kunt and Levine (2004), Sweden is, despite its reliance on banks, classified as having a market-based system. iii The classification as being market-based arises partly from the large share of deposits that are claimed by non-bank financial intermediaries, such as insurance companies, mutual funds, and pension funds.iv This might occur since Sweden's pension system is such that a certain percentage of an individual's income is continuously placed in pension funds. Since the bank sector is small in relation to the stock market, it is also interpreted as evidence that Sweden has a market-based system. Sweden and in particular Stockholm, is the financial center in the Nordic countries leading to a large stock market in relation to the domestic bank market. Hence, the classification by Demirguc-Kunt and Levine do not contradict the fact that start-ups in Sweden rely on banks for external financial funds.

The largest groups in the Swedish financial market are banks, mortgage lenders, and insurance companies. The different categories of banks, Swedish-owned commercial banks, foreign-owned commercial banks, savings banks, and credit unions represent 39 percent of the total balance sheet value in the financial market in 2010. Commercial banks focus on short-term credits for businesses. Savings banks act more at the local and regional level with bank branches and head offices located in small and medium-sized regions. The difference between savings banks and commercial banks is that savings banks have a more profound local agenda. Their objective is to strengthen and develop the municipality or the region where they are located. Credit unions are economic associations serving their own members (Svenska Bankföreningen, 2010).

The commercial banks have the largest market shares in Sweden and comprise four main bank corporations: Swedbank, Nordea, Handelsbanken, and SEB. These four corporations are the most important actors on the deposit and lending market from and to the Swedish population. Roughly 70 percent of the total number of bank branches belongs to these four corporations (Svenska Bankföreningen, 2010). Among the bank branches there is often a hierarchical structure where smaller bank branches are not allowed to grant large loans without briefing the regional or central level (Handelsbanken, 2008). Even though the networks of 
bank branches cover all municipalities, Sweden has a low bank branch density compared to other European countries (Svenska Bankföreningen, 2010). Due to the dominance of the four large bank corporations, the Swedish bank system has an oligopoly-like structure.

\section{Local bank sector and new firm formation}

Entrepreneurial theories have treated accessibility of financial capital differently. Cantillon (1755), Marshall (1890), Schumpeter (1934), and Kirzner (1973) assume that individuals can borrow the needed capital in a perfectly functioning capital market. Others argue that the capital market is characterized by imperfect and asymmetric information and that financial capital can be borrowed only if the firm founder has a certain reputation in advance (Say, 1803), or if the entrepreneur can persuade the bank that he/she has a valid and profitable idea (Knight, 1921).

If there were no frictions in the financial market, a profitable project would find sufficient financial funds at a competitive price. There are, however, market barriers for new firms since credit rationing tends to exist (Stiglitz and Weiss, 1981; Evans and Jovanovic, 1989), i.e. a situation where individuals cannot obtain the necessary financial funds for what they see as viable ventures. The market barriers for new firms consist of large information and transaction costs (Cestone and White, 2003). Banks can play an important role in this context since a bank's raison d'être is to mitigate information and transaction costs in order to facilitate allocation of financial resources (Levine, 1997).

In order for a bank to finance a project, it needs to assess two uncertain factors: whether the project is profitable and whether the firm founder is reliable and capable. It is a classic case of asymmetric information where the firm founder has more information than the bank (Akerlof, 1970). Storey and Wynarczyk (1996) analyse factors influencing firm survival and conclude that it is the firm and location characteristics that are important rather than the individual characteristics of the firm founder. Hence, the bank cannot use the characteristics of the firm founder to forecast the success of a firm.

Start-ups have by definition a limited firm history and are perhaps the most informational-opaque firms (Cassar, 2004). In order for the firm founder to communicate information about the project to the bank, time- 
consuming and costly face-to-face contacts are needed (Gereffi et al., 2005). The spatial reach for such banking services is limited, so firm founders often approach bank branches in the local and regional environment (Berger et al., 1999; Kwast, 1999; Collender and Shaffer, 2003). By doing so, the firm founders' local social network built on family, education, religion, gender, and ethnicity can be used (Michelacci and Silva, 2007).

The use of local knowledge, i.e. "the knowledge of particular circumstances of time and place" (Hayek, 1945, p. 521), applies to both firm founders and bank branches. It is in particular applicable to firm founders since they hold extensive information about their project, the start-up, but also to the bank branch. Local banks have access to knowledge about the local market in which a potential firm will act, about the firm's potential collaboration partners, investment opportunities, and potential board members. Banks in Germany spend more than 75 percent of their total investments within a distance of 100 kilometers, often a result of their regional networks which provide the banks with comparative advantages (Fritsch and Schilder, 2008). First, the asymmetric information is reduced in loan contracts by increased knowledge about local entrepreneurs, firms, and projects. Second, banks can benefit from "information in the air" concerning local economic conditions that can be used in lending decisions (Pollard, 2003).

An increase in the number of independent banks in a region has several effects for a given borrower, according to Thakor (1996). With an increase in independent banks, a borrower can send a request of financial funds to multiple banks. More independent banks will increase the probability that at least one bank will accept the financial request after a screening process. Thus, the probability of receiving credit increases with the number of independent banks present in a location. The physical presence of banks is not the only prerequisite for the rate of start-ups to increase. The market structure of the local bank sector also influences the access to financial capital. The size of the local bank branches gives an indication about their structure and available services. Larger bank branches are created by the existence of a division of labor in banking (Lieberson, 1961). An increase in size of operations results in a higher degree of specialization (Francois, 1990). Specialization has several advantages: (1) enhanced human capital of employees, (2) time- and effortsavings by focusing on one process, and (3) facilitated innovations (Smith, 2001[1776]; Stigler, 1951, Duranton 
and Puga, 2004). Bolton and Dewatripont (1994) find that firms can minimize time spent on absorbing new information due to specialization. Larger bank branches can thus reap a comparative advantage in handling information due to specialization and can hence accumulate specific knowledge about, for example, different sectors. This type of knowledge is vital in the case of new firm formation. With increased knowledge, fewer loans will be denied on account of asymmetric information about the value of the new firm (Parker, 2004). Small bank branches have a disadvantageous position in this context might since they have inadequate ability to verify the quality of a financial request. Hence, the assumption is that new firm formation is enhanced in regions with on average larger bank branches.

Whether competition, low degree of market power, in the bank sector is beneficial or not for the rate of start-ups has been widely debated. Some claim that increased market power reduces the equilibrium amount of credit. Others argue that some level of market power is needed in order for a bank to establish fruitful lending relationships. Following the last statement, Petersen and Rajan (1995) find that new firms benefit if banks have more market power, i.e. a lower competition level. The access to potentially available credit increases since it is easier for a new firm to establish a relationship with the bank. Petersen and Rajan state that it is easier for creditors to internalize the benefits of financing a firm since long-term relationships between a bank and a borrower are easier to maintain in a less competitive environment. The accumulated information enables the bank to make better credit decisions. Hence a long-term relationship enables banks to seize future profit opportunities from a firm. In a competitive market, the lender would not be as certain to benefit from future profit streams and could therefore not cover the cost of engaging in new relationships. The bank would then have to charge a higher interest rate or would not engage in new relationships at all, leaving some firm founders without any financial funds or at a higher cost. This suggests that a local bank sector with a low competition level increases the rate of start-ups.

On the other hand, the amount of available credit can be reduced because of market power. The access of firms to financial funds increases in a more competitive environment (Berger et al., 1999; Dinc, 2000; Beck et al., 2004; Cetorelli, 2004; Dell'Ariccia and Marquez, 2004). Banks operating in less competitive markets tend to favor old customers over new. The profitability of mature firms is assumed to decrease with new entrants, and 
since they are the bank's customers, the bank's profitability will decrease as well. Already established relationships between firms and banks can hence negatively affect the probability of new firms accessing financial funds (Spagnolo, 2000; Cestone and White, 2003). Thus, a lower level of competition on the financial market acts as a barrier to new entrants. Market power can also lead to borrowers being faced with a lower credit supply and a higher rent (Cetorelli and Strahan, 2006). If this is the case, it justifies antitrust enforcement. Less available credit affects all firms in a region but new firms are potentially more vulnerable since they rely more on bank credit compared to established firms. A more competitive environment is thereby identified to increase the probability of accessing financial funds and hence strengthens business creation.

Firm founders are typically forced to rely on bank financing in all locations since this is the dominating external source of finance in Sweden. Some sites are, however, more reliant on bank financing since other options such as venture capital and business angels are scarce. Large metropolitan regions supply more sources of external finance (Bygrave, 1988; Murray, 1998). The capital also stays within these regions since the investment requires proximity and frequent face-to-face contacts between investors and firm founders. Venture capital, for example, flees from locations faced with staggering growth and is invested in more prosperous regions (Leinbach and Amrhein, 1987; Florida and Kenney, 1988; Keeble, 1989). The need for external finance is also shaped by the industrial structure in a location. Manufacturing firms tend to need more financial capital since they invest more heavily in physical capital than service firms (Parker, 2004).

In sum, the proposed hypothesis is that the local bank sector is an important factor that shapes the local economic environment and so affects the rate of new firm formation. The main argument put forward in this section is that the local bank sector influences the new firm formation rate. This view has, however, been questioned by Robinson (1952), suggesting that financial intermediaries follow firms. Many new firms in a region might create a demand for financial services and hence influence the market structure of the local bank sector. Hence, the causality issue is of importance in this paper. The causality relationship between financial development and growth has been extensively examined. Studies confirm a positive first-order relationship between financial development and economic growth (King and Levine, 1993a, 1993b; Levine, 1997; Rajan 
and Zingales, 1998). Thus, financial development is followed by economic growth in terms of gross national product and industry growth through the emergence of new firms. Since new firms are informational-opaque and face large transaction costs, their access to financial funds might be limited. If the financial sector develops and eases the frictions, new and small firms will benefit (Cestone and White, 2003). Beck et al. (2008) find that financial development increases the access to financial services for start-ups.

\section{Data and description of variables}

The dataset used in this paper originates from Statistics Sweden and covers variables at the municipal level for year 2010. The new firm formation variable is constructed by Statistics Sweden using firm-level data aggregated to the municipal level. It is unfortunately not possible to access the firm-data and find out specific details about each individual firm. A firm is registered as a new firm if a new organization number is identified and the majority of the employees are new, i.e. if they did not work in the firm before the organization number was changed. New firms that arise due to division of firms or mergers of already existing firms are not registered as new firms. Only firms with economic activity are analysed for each year, i.e. firms that report VAT and/or payroll tax. Thus, by using these criteria only actual new active establishments are included in the sample.

The data for the local bank sector are based on detailed statistics for each bank branch: name, coordinates, and number of employees. From this, it is possible to identify the type of bank, such as savings or commercial banks and find out to which independent bank each bank branch belongs. This information has then been aggregated to the municipal level.

\subsection{Variables}

The total number of start-ups in a municipality is standardized by the number of individuals in the labor force, referred to as the labor market approach. Start-ups can also be related to the existing population of firms, referred to as the ecological approach (Audretsch and Fritsch, 1994). In the labor market approach all individuals in the labor force are potential firm founders. A convincing argument in favor of the labor market 
approach is that it recognizes that it is mostly individuals and not firms that start new firms (Evans and Jovanovic, 1989). Additional support for this approach is the finding that most firm founders tend to start their business close to their residence (Mueller and Morgan, 1962; Sorenson and Audia, 2000). In addition, the labor market approach is not sensitive to the average firm size in a region.

Banks are defined according to the Standard International Classification code 65120, which includes commercial and savings banks. The independent variables in focus are those capturing different features of the local bank sector. The average size of the bank branches gives an indication about specialization possibilities. A smaller average size indicates that the bank branch might not have the adequate capacity or authority to grant loans needed for start-ups. The variable is based on data of the value of the total number of bank branches and employment in each municipality collected from employment statistics. The number of independent banks and bank branches divided by the population in location $r$ is included to represent the possible places for a firm founder to access financial funds. A dummy indicating whether there are any savings banks in the municipality gives an indication of the presence of banks with a profound local agenda.

The market structure is also captured by the competition level. Information about bank branch activity (deposits) is often used to measure concentration. Such information is not available in the dataset. Concentration is instead measured through the employment of each bank branch using a HerfindahlHirschman index (HHI). The HHI makes use of the entire distribution of bank sizes but larger branches are given a greater weight than smaller branches. The HHI is perhaps the most widely used concentration measure in the financial literature and is presented in Equation 1.

$$
H H I_{r}=\sum_{i=1}^{n}\left(\frac{e_{i r}}{e_{r}}\right)^{2}
$$

where $H H I_{r}$ represents the employee concentration in the bank sector in locality $r, e_{i r}$ is the employment in the bank branch $i$ in location $r, e_{r}$ is the total employment in the bank sector in location $r$, and $n$ is the number of bank branches. The $H H I_{r}$ measures the distribution of employees across branches. The $H H I_{r}$ ranges between $1 / n$ and 1 , where unity signifies monopoly and low values indicate similar sizes of the bank branches. By taking the inverse of the $H H I_{r}$ a measure for the local competition level is established, following Martin et 
al. (2011). The competition index is measured as Competition $_{r}=\left(1 / H H I_{r}\right)$ and ranges from one (monopoly) to $n$ (full competition). Due to the structure of the data the exact number of employees for each bank branch is not accessible. The only information is to what size class the bank branch belongs. ${ }^{*}$ Due to this, each bank branch is assigned the mean value of the size class. It should be noted that a concentration measure does not necessarily capture the competitive level. It is possible to have competition among the leading banks in a highly concentrated market.

The local bank sector is portrayed by two different geographical classifications: municipality $s$ and functional region $f$. Hence, location $r$ could be the municipality or the functional region. The average travel time by car within a municipality is approximately 5-15 minutes. A functional region corresponds to a local labor market and is normally composed of several municipalities. In Sweden, there are 290 municipalities that can be grouped into 81 functional regions. The average time travel by car within a functional region is roughly 15-50 minutes (Johansson et al., 2003).

Many factors have been emphasized in previous studies as being important in empirical studies of new firm formation. For an extensive discussion about entry conditions on the Swedish market, see Nyström (2006). Factors that are commonly used in studies about regional start-ups are the structure of the local market, government support, access to human capital, unemployment, and industrial structure. These factors have been studied extensively and are used as control variables in this paper, presented in Table 1. 


\section{Table 1 Description of variables}

\begin{tabular}{|c|c|c|c|}
\hline Indicator & Description & References & $\begin{array}{l}\text { Exp. } \\
\text { sign }\end{array}$ \\
\hline New firm formation rate & $\begin{array}{l}\text { Total number of new firms divided } \\
\text { by the labor force, in municipality } s\end{array}$ & & $\begin{array}{l}\text { Dep. } \\
\text { var }\end{array}$ \\
\hline Quality of the bank sector & $\begin{array}{l}\text { Average bank branch employment, } \\
\text { in municipality } s\end{array}$ & See Section 3 & + \\
\hline $\begin{array}{l}\text { Possible places to access } \\
\text { financial funds }\end{array}$ & $\begin{array}{l}\text { Individual banks per capita } \\
\text { (municipality or functional region) }\end{array}$ & See Section 3 & + \\
\hline $\begin{array}{l}\text { Possible places to access } \\
\text { financial funds }\end{array}$ & $\begin{array}{l}\text { Bank branches per capita } \\
\text { (municipality or functional region) }\end{array}$ & See Section 3 & + \\
\hline $\begin{array}{l}\text { Banks with a profound } \\
\text { local agenda }\end{array}$ & $\begin{array}{l}\text { Dummy indicating presence of } \\
\text { savings bank, in municipality } s, \\
1=\text { presence, } 0=\text { otherwise }\end{array}$ & See Section 3 & + \\
\hline Bank competitive level & $\begin{array}{l}\text { Inverse Herfindahl-Hirschman } \\
\text { index (HHI) (municipality or } \\
\text { functional region) }\end{array}$ & See Section 3 & $+/-$ \\
\hline Human capital intensity & $\begin{array}{l}\text { Proportion of labor force with } \\
\text { three or more years of higher } \\
\text { education, in municipality } s\end{array}$ & $\begin{array}{l}\text { Johansson and Wigren, 1996; } \\
\text { Malmberg et al., 1996; Malmberg and } \\
\text { Maskell, 1997; Parker, 2004; Karlsson } \\
\text { and Backman, 2011) }\end{array}$ & + \\
\hline Industry structure & $\begin{array}{l}\text { Mean establishment size, in } \\
\text { municipality } s\end{array}$ & $\begin{array}{l}\text { (Mason, 1991; Fritsch, 1992; Boden, } \\
\text { 1996: Parker, 2004) }\end{array}$ & - \\
\hline Firm density & $\begin{array}{l}\text { Number of firms divided by the } \\
\text { population, in municipality } s\end{array}$ & (Porter, 1990; Ciccone and Hall, 1996) & + \\
\hline Change in demand & $\begin{array}{l}\text { Change in population from } 2009 \text { to } \\
2010 \text {, in municipality } s\end{array}$ & $\begin{array}{l}\text { (Reynolds et al., 1994; Armington and } \\
\text { Acs, 2002; Sutaria and Hicks, 2004; van } \\
\text { Stel and Suddle, 2008) }\end{array}$ & + \\
\hline
\end{tabular}




\begin{tabular}{|c|c|c|c|}
\hline Push or pull factor & $\begin{array}{l}\text { Unemployment rate, proportion of } \\
\text { labor force registered as } \\
\text { unemployed, in municipality } s\end{array}$ & $\begin{array}{l}\text { (Binks and Jennings, 1986; Audretsch } \\
\text { et al., 2001; Parker, 2004; Sutaria and } \\
\text { Hicks, 2004) }\end{array}$ & $+/-$ \\
\hline $\begin{array}{l}\text { State subsidies for start- } \\
\text { ups }\end{array}$ & $\begin{array}{l}\text { Average monthly number of state } \\
\text { subsidies to start-ups, in } \\
\text { municipality } s\end{array}$ & $\begin{array}{l}\text { (Reynolds et al., 1994; McQuaid, 2002; } \\
\text { Feldman et al., 2005) }\end{array}$ & + \\
\hline Regional structures & $\begin{array}{l}\text { Dummy indicating urban-rural } \\
\text { character of municipality } s \text {, } \\
1=\text { urban, } 0=\text { rural }\end{array}$ & $\begin{array}{l}\text { (Ashcroft et al., 1991; Renski, 2008; } \\
\text { Berggren and Silver, 2010) }\end{array}$ & \\
\hline
\end{tabular}




\subsection{Descriptive statistics}

Table 2 provides the descriptive statistics in 2010 for the full sample.

Table 2 Descriptive statistics in 2010, full sample

\begin{tabular}{|c|c|c|c|c|c|}
\hline & Mean & Median & Std. Deviation & Min. & Max. \\
\hline New firm formation rate & 0.01 & 0.01 & 0.003 & 0.006 & 0.03 \\
\hline Average bank branch employment, municipal level & 12.30 & 8.73 & 19.26 & 2 & 303.86 \\
\hline Individual banks, municipal level & 3.39 & 3 & 2.37 & 1 & 33 \\
\hline Bank branches, municipal level & 6.18 & 4 & 13.46 & 1 & 202 \\
\hline Individual banks per capita, municipal level & $1.88 \mathrm{e}-4$ & $1.60 \mathrm{e}-4$ & $1.19 \mathrm{e}-4$ & $1.95 e-5$ & $8.13 e-4$ \\
\hline Bank branches per capita, municipal level & $2.48 \mathrm{e}-4$ & $2.19 \mathrm{e}-4$ & $1.29 \mathrm{e}-4$ & $7.55 e-5$ & $8.13 \mathrm{e}-4$ \\
\hline $\begin{array}{l}\text { Dummy indicating presence of savings bank, } \\
1=\text { presence, } 0=\text { otherwise, municipal level }\end{array}$ & 0.44 & 0 & 0.50 & 0 & 1 \\
\hline Inverse HHI, municipal level & 2.98 & 2.52 & 1.82 & 1 & 16.62 \\
\hline Individual banks per capita, functional region & $1.41 \mathrm{e}-4$ & $1.16 \mathrm{e}-4$ & $9.08 \mathrm{e}-5$ & $5.73 e-5$ & $7.31 \mathrm{e}-4$ \\
\hline Bank branches per capita, functional region & $2.17 \mathrm{e}-4$ & 1.90 e -4 & $9.09 \mathrm{e}-5$ & $1.04 \mathrm{e}-4$ & $7.31 \mathrm{e}-4$ \\
\hline Inverse $\mathrm{HHI}$, functional region & 0.73 & 0.41 & 0.93 & 0.09 & 7.87 \\
\hline $\begin{array}{l}\text { Proportion of labor force with three or more years of } \\
\text { higher education, municipal level }\end{array}$ & 0.09 & 0.08 & 0.05 & 0.03 & 0.38 \\
\hline Mean establishment size, municipal level & 6.46 & 6.10 & 2.00 & 3.18 & 15.05 \\
\hline $\begin{array}{l}\text { Number of firms divided by the population, municipal } \\
\text { level }\end{array}$ & 0.06 & 0.06 & 0.01 & 0.03 & 0.11 \\
\hline $\begin{array}{l}\text { Change in population from } 2009 \text { to } 2010 \text {, municipal } \\
\text { level }\end{array}$ & 261.20 & 6.50 & 1203.66 & -303 & 17656 \\
\hline Unemployment rate, municipal level & 0.04 & 0.04 & 0.01 & 0.02 & 0.07 \\
\hline $\begin{array}{l}\text { Average monthly number of state subsidies to start- } \\
\text { ups, municipal level }\end{array}$ & 15.52 & 8.08 & 31.26 & 0.33 & 375.08 \\
\hline
\end{tabular}


The average number of individual banks in Swedish municipalities is slightly above three and the average number of bank branches is just over six. The average municipality offers good access to financial capital. There are, however, large differences as indicated by the minimum and maximum values. The independent banks and bank branches per capita at the municipal and functional region levels presents the same pattern of large differences with a large span between the minimum and maximum values. There are also large differences in the competition level, proxied by the inverse Herfindahl-Hirschman index. Savings banks are present in 44 percent of the municipalities. Table 3 shows the correlation between the different measures of the local bank sector. 
Table 3 Correlation matrix, measures of the local bank sector in 2010

\begin{tabular}{|c|c|c|c|c|c|c|c|c|c|}
\hline & $\begin{array}{l}\text { New firm } \\
\text { formation } \\
\text { rate }\end{array}$ & Av. size & $\begin{array}{c}\mathrm{b} / \\
\text { pop } \\
\text { (mun) }\end{array}$ & $\begin{array}{l}\text { i/ pop } \\
\text { (mun) }\end{array}$ & $\begin{array}{l}\text { D sav. } \\
\text { Bank } \\
\text { (mun) }\end{array}$ & $\begin{array}{c}1 / \\
\mathrm{HHI} \\
\text { (mun) }\end{array}$ & $\begin{array}{l}\text { b/ pop } \\
\text { (fr) }\end{array}$ & $\begin{array}{l}\text { i/ } \\
\text { pop } \\
\text { (fr) }\end{array}$ & $\begin{array}{c}1 / \\
\text { HHI } \\
\text { (fr) }\end{array}$ \\
\hline $\begin{array}{l}\text { New firm } \\
\text { formation rate }\end{array}$ & 1 & - & - & - & - & - & - & - & - \\
\hline $\begin{array}{l}\text { Average bank } \\
\text { branch } \\
\text { employment (Av. } \\
\text { size) }\end{array}$ & $0.045^{*}$ & 1 & - & - & - & - & - & - & - \\
\hline $\begin{array}{l}\text { Individual banks } \\
\text { per capita } \\
\text { municipal level } \\
\text { (b/pop (mun)) }\end{array}$ & $0.389 *$ & $-0.228 *$ & 1 & - & - & - & - & - & - \\
\hline $\begin{array}{l}\text { Bank branches } \\
\text { per capita } \\
\text { municipal level } \\
(\mathrm{i} / \text { pop (mun)) }\end{array}$ & $0.501 *$ & $-0.216^{*}$ & $0.828^{*}$ & 1 & - & - & - & - & - \\
\hline $\begin{array}{l}\text { Dummy savings } \\
\text { bank municipal } \\
\text { level (D sav. } \\
\text { Bank (mun)) }\end{array}$ & 0.083 & -0.020 & 0.085 & 0.151 & 1 & - & - & - & - \\
\hline $\begin{array}{l}\text { Inverse } \mathrm{HHI} \text {, } \\
\text { municipal level } \\
(1 / \mathrm{HHI}(\mathrm{mun}))\end{array}$ & $0.130 *$ & $0.159 *$ & $-0.363^{*}$ & -0.113 & -0.093 & 1 & - & - & - \\
\hline $\begin{array}{l}\text { Individual banks } \\
\text { per capita, } \\
\text { functional region }\end{array}$ & $0.343^{*}$ & $-0.158^{*}$ & $0.659 *$ & $0.589 *$ & $0.126^{*}$ & $-0.188^{*}$ & 1 & - & - \\
\hline
\end{tabular}




\begin{tabular}{l|c|c|c|c|c|c|c|c|c}
\hline (b/pop (fr)) & & & & & & & & & \\
\hline Bank branches & & & & & & & & & \\
per capita, \\
functional region \\
(i/pop (fr))
\end{tabular}

*significant at the five percent level

The only variable used to describe the local bank sector that does not have a significant correlation with the dependent variable is the dummy indicating the presence of savings banks. In all the other cases correlations are positive and significant. The highest bivariate correlation is found for bank branches per capita in the municipality and in the functional region. Due to the high bivariate correlation among some of the covariates' describing the local bank sector (bank branches and independent banks per capita at the municipal and the functional region level) they are estimated in separate specifications. The high correlation among these variables is of no surprise since a location with many independent banks naturally also has many bank branches. The estimated model is presented in Equation 2.

$$
N F F_{s}=\alpha+X_{s}^{\prime} \beta+Z_{s}^{\prime} \delta+\varepsilon_{s}
$$

where $N F F_{S}$ is the new firm formation rate in municipality $s$ explained by a vector of variables characterizing the local bank sector, $X_{S}^{\prime}$, and a set of control variables, $Z_{s}^{\prime}$, presented in Table 1. $\beta$ and $\delta$ are vectors of parameters and $\varepsilon_{S}$ is the error term. The local bank sector is in this paper described by several variables. The nuanced picture enables a better analysis of the local bank sector, which is a clear strength. The trade-off of using a cross-sectional model instead of a panel model is that it is not possible to control for unobserved heterogeneity among municipalities. ${ }^{\mathrm{vi}}$ Measures of the local bank sector might partly be endogenous if the number of independent banks and bank branches is higher in municipalities where new firm formation is high 
for other exogenous reasons. To overcome the endogeneity problem, an instrumental variable approach is applied in this paper. A two-stage least square (2SLS) is used where the same variables in 1995 instrument the local bank sector in 2010.vii One additional instrument is used, and it measures the number of savings banks in each municipality in 1895. The instruments fulfill the relevance condition since they are correlated with the endogenous variables verified by significant estimates in the first-stage equation, high pairwise correlation, high partial R-square, and by high F-values (above 10) leading to a rejection of the null hypothesis of weak instruments. The validity condition implies that the instruments are exogenous, i.e. not correlated with the error term. Instrument validity relies on theory and norms established in other empirical work (Cameron and Trivedi, 2009). A factor in favor of the instruments is their historical characteristics, based on data prior to the year of estimation. Similar instruments have been used in Bonaccorsi di Patti and Dell'Ariccia (2004) and Combes et al. (2010). The Sargan test of overidentification can, however, be used since we have more instruments than endogenous variables. The p-values in this test are above ten percent for the estimated models and the null hypothesis of valid instruments cannot be rejected. One should interpret this result with

care since a rejection of the null hypothesis does not grant that all instruments are valid. An ordinary least square (OLS) and the 2SLS are compared using a Hausman test, where the null hypothesis that there is a systematic difference between the coefficients in the OLS and the 2SLS is rejected at the five percent level, given support for the 2SLS model.

\subsection{Spatial patterns in the location of banks}

The next step is to investigate the geographical distribution of new firms and the locations of banks. Figure 1 illustrates new firm formation related to the labor force in each municipality in 2010. Figure 2 shows the exact location of all bank branches in 2010, divided into two categories: commercial banks and savings banks, based on their coordinates. 


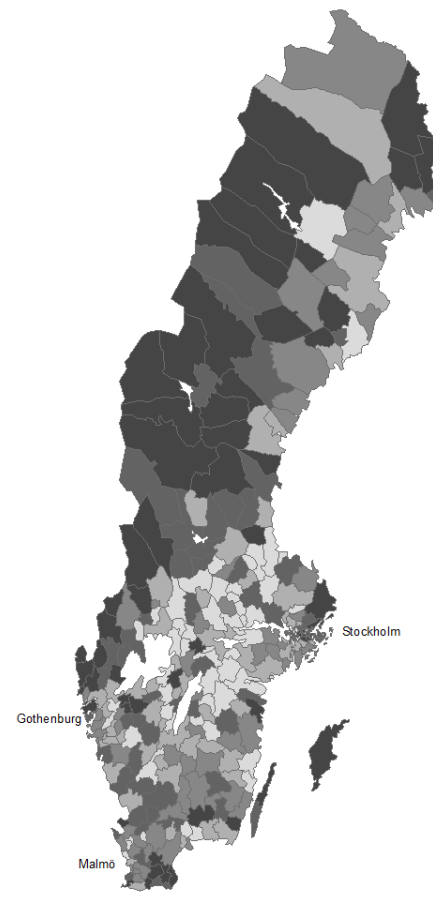

New firm formation rate, quantile

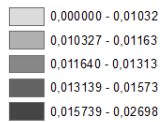

\section{Figure 1 New firm formation rate, 2010}

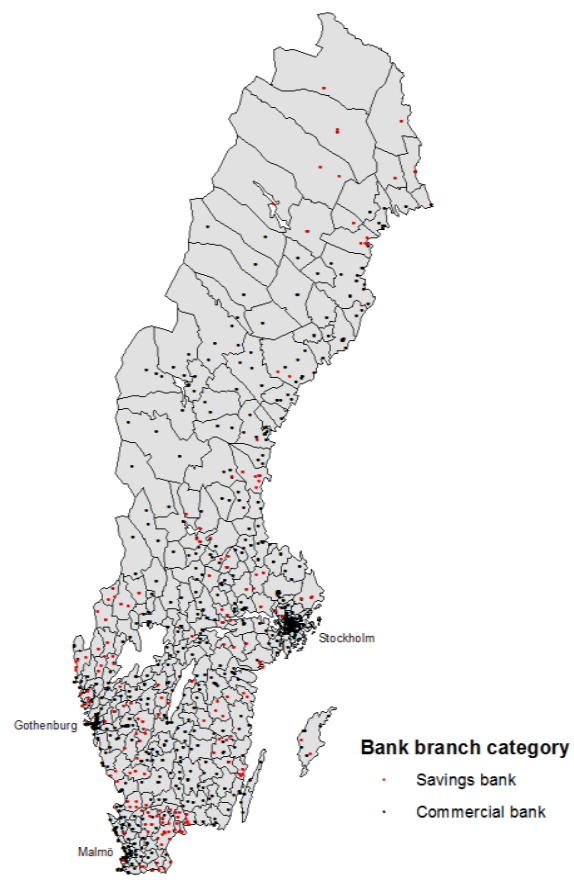

Figure 2 Bank branch location, commercial and savings banks, 2010

There are many municipalities in the north of Sweden that have a high rate of new firm formation. This is mainly due to the small labor force size in these municipalities, affecting the denominator when calculating the new firm formation rate. The south central inland of Sweden has a lower new firm formation rate. In order to mitigate effects from unobservable factors in different municipalities, different regional settings are used in the estimation.

Bank branches are spread out all over Sweden but south Sweden has a higher concentration as indicated in Figure 2. In addition, bank branches cluster in the three largest cities, Stockholm, Gothenburg and Malmö. The bank branches that are affiliated with savings banks tend to have a higher concentration in the very south of Sweden. 
To deepen the understanding of the geographical distribution of banks in Sweden a Getis-Ord Gi* clustering analysis is used. This gives information about spatial dependencies and spatial clustering. Global Moran's I cannot be used since it does not give any insights into the locational distribution of spatial autocorrelation, as indicated by the name. Getis-Ord $\mathrm{Gi}^{*}$ is used to detect spatial patterns in the data if locations with high (low) values are clustered in space. Clusters of such high (low) values are often referred to as hot (cold) spots. It is the Z-score that gives information about the potential hot and cold spots, i.e. a high positive Z-score indicates a hot spot and low negative values indicate cold spots. Figures 3 and 4 show the local spatial dependencies for the number of independent banks and bank branches in 2010, using Getis-Ord Gi*.
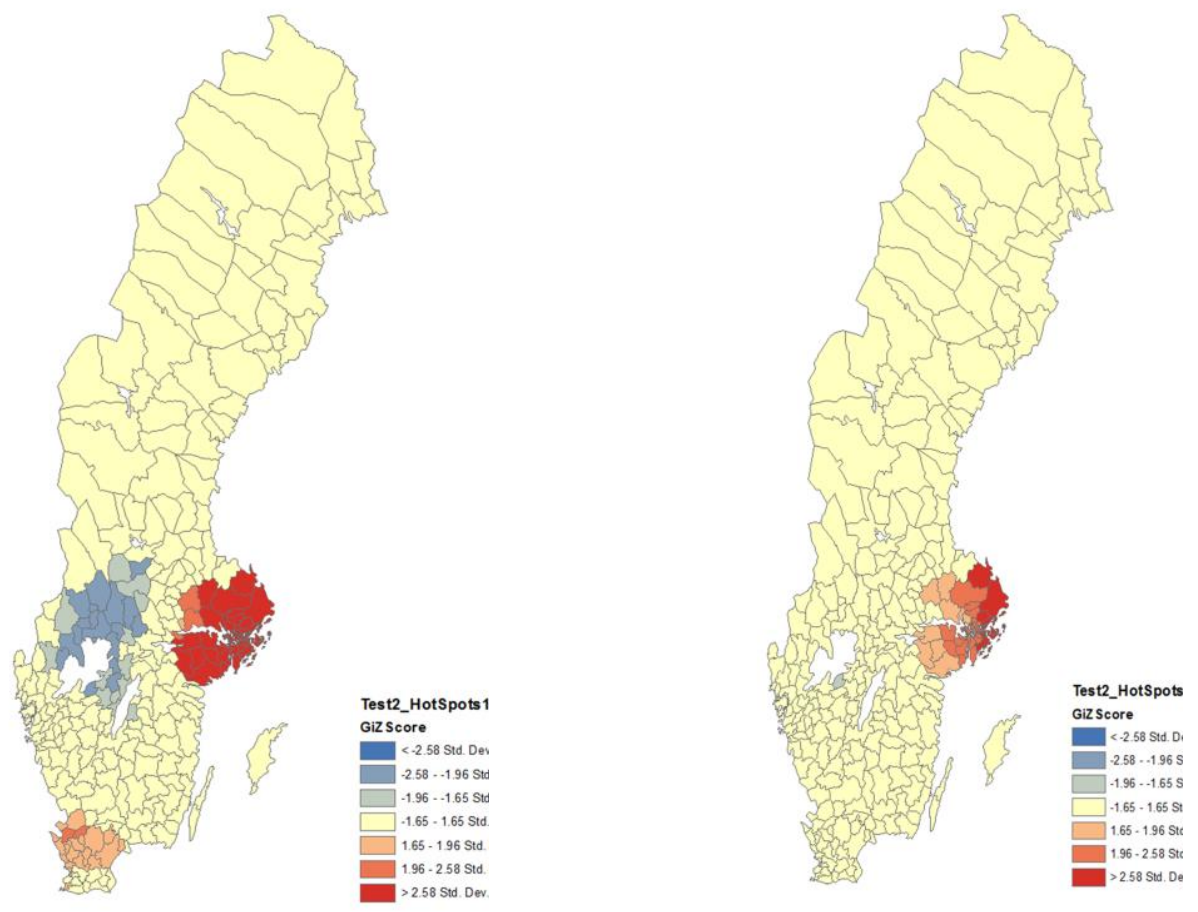

Figure 3 Getiz-Ord Gi* clustering using the number of independent banks

Figure 4 Getiz-Ord Gi* clustering using the number of bank branches

As indicated by the maps, there are few hot -spots in Sweden outside of the largest metropolitan region in Sweden, Stockholm. That Stockholm is a hot-spot concerning both the number of independent banks and the 
number of bank branches is no surprise since Stockholm is the financial center in Sweden and in the whole set of Nordic countries. In the case of bank branches there is no hot- or cold- spot outside of Stockholm. Thus, bank branches are evenly spread in Sweden. There is however one hot- spot and one cold- spot in the case of independent banks. The hot-spot is located in the very South of Sweden, but is not only an effect from the metropolitan region of Malmö. Many savings banks are located in this region, indicated by the many bank branches that belong to savings banks in this region, in Figure 2. The cold-spot north of the largest lake in Sweden comprise areas that are sparsely populated and with relatively few savings banks branches.

\section{Empirical results}

Table 4 shows the results from estimating Equation 2 by means of a 2SLS in 2010. The estimations use Huber-White-sandwich estimate of variance to adjust for heteroscedasticity. All variables are transformed into natural logarithms except the dummy variables and the variable indicating the change in population since this is negative for some municipalities. Due to the high correlation among some of the variables used to describe the local bank sector, see Table 3, they cannot be estimated together and the model is therefore split into two

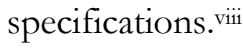

\section{Table 4 New firm formation and its relationship with the local bank sector, 2SLS}

\begin{tabular}{l|r|r}
\hline Dependent variable: Proportion of new firm formation (ln) & Spec.1 Spec.2 \\
\hline & $0.126^{*}$ & $0.149^{* *}$ \\
\hline Average bank branch employment, municipal level $(\ln )$ & $(0.065)$ & $(0.065)$ \\
\hline Individual banks divided by the population, municipal level $(\ln )$ & $0.309^{* *}$ & - \\
\hline Bank branches divided by the population, municipal level $(\ln )$ & $(0.068)$ & $(0.065)$ \\
\hline Dummy indicating presence of savings bank, $1=$ presence, $0=$ otherwise, & - & $0.366^{* *}$ \\
\hline
\end{tabular}




\begin{tabular}{|c|c|c|}
\hline $\begin{array}{l}\text { Inverse Herfindahl-Hirschman index, based on number of employees, municipal } \\
\text { level }(\mathrm{ln})\end{array}$ & $\begin{array}{l}0.188^{* *} \\
(0.076)\end{array}$ & 0.019 \\
\hline Individual banks divided by the population, functional region $(\ln )$ & - & $\begin{array}{l}-0.018 \\
(0.071)\end{array}$ \\
\hline Bank branches divided by the population, functional region (ln) & $\begin{array}{l}-0.001 \\
(0.151)\end{array}$ & - \\
\hline $\begin{array}{l}\text { Inverse Herfindahl-Hirschman index, based on number of employees, functional } \\
\text { region }(\ln )\end{array}$ & 0.032 & 0.015 \\
\hline $\begin{array}{l}\text { Proportion of labor force with three or more years of higher education, } \\
\text { municipal level (ln) }\end{array}$ & $\begin{array}{l}0.331 * * \\
(0.059)\end{array}$ & $\begin{array}{l}0.297 * * \\
(0.055)\end{array}$ \\
\hline Mean establishment size, municipal level (ln) & $\begin{array}{c}-0.745^{* *} \\
(0.093)\end{array}$ & $\begin{array}{c}-0.689 * * \\
(0.081)\end{array}$ \\
\hline Number of firms divided by the population, municipal level (ln) & $\begin{array}{l}0.289 \\
(0.218)\end{array}$ & $\begin{array}{l}0.269^{* *} \\
(0.123)\end{array}$ \\
\hline Change in population from 2009 to 2010 , municipal level & $\begin{array}{l}0.016^{* *} \\
(0.008)\end{array}$ & $\begin{array}{l}-0.003 \\
(0.008)\end{array}$ \\
\hline Unemployment rate, municipal level (ln) & $\begin{array}{l}0.041 \\
(0.055)\end{array}$ & $\begin{array}{l}0.039 \\
(0.050)\end{array}$ \\
\hline Average monthly number of state subsidies to start-ups, municipal level (ln) & $\begin{array}{l}-0.004 \\
(0.017)\end{array}$ & $\begin{array}{l}-0.007 \\
(0.012)\end{array}$ \\
\hline $\begin{array}{l}\text { Dummy urban-rural } \\
1=\text { urban, } 0=\text { rural }\end{array}$ & $\begin{array}{l}-0.057 \\
(0.032)\end{array}$ & $\begin{array}{l}-0.004 \\
(0.026)\end{array}$ \\
\hline Constant & $\begin{array}{l}1.240 \\
(0.845)\end{array}$ & $\begin{array}{l}1.281 * \\
(0.592)\end{array}$ \\
\hline $\mathrm{N}$ (municipalities) & 290 & 290 \\
\hline $\mathrm{R}^{2}$ & 0.44 & 0.56 \\
\hline
\end{tabular}

Robust standard errors in parentheses, ${ }^{* *}$ significant at one percent, ${ }^{*}$ significant at five percent. The variables describing the local bank sector is instrumented with the same variables in 1995 and the number of savings banks in 
each municipality in 1895.

\subsection{Local bank sector: full sample}

The average size of a bank branch is positively associated with new firm formation. The elasticity ranges between 0.126 and 0.149 indicating that if the size of an average bank branch grows by ten percent, the new firm formation rate increases by 1.3 to 1.5 percent. Considering that most rural municipalities have a small average bank branch size, a ten percent increase in the average size of a bank branch means increasing the staff by one person. Also, the new firm formation rate is measured as new firms standardized with the labor force, indicating that even a small increase in the new firm formation rate can in practice mean the creation of a new firm. The result indicates that new firms benefit from the fact that employees in larger bank branches can specialize in specific sectors, markets, or types of firms and in this way be more efficient in handling information and monitoring start-ups. Expertise knowledge can also be accumulated through experience, which leads to better judgments about new firm formations (Storey, 1994). There is also a hierarchical structure of bank branches in Sweden. Smaller bank branches are not always allowed to grant large loans without briefing the regional or central level. If a municipality only has small bank branches, the decision is taken in another location. Bank branches higher up in the hierarchy might have less knowledge about particular circumstances for a given project and specific local information. Decisions not taken at the actual location lead to more bureaucratic costs and loss of knowledge, which can have a negative effect on the probability that a loan request will be granted and thereby influence the access to financial funds for a firm founder. It is, however, impossible to model the links between the bank branches on the different hierarchical levels due to lack of data.

The number of bank branches and the number of independent banks per capita are positive and significant at the municipal level but insignificant when measured at the functional region level. This indicates that the relative number of branches and banks plays a role for start-ups at the local, municipal, level. A larger number of independent banks and bank branches represents more places where a firm founder can request financial funds and indicates a higher probability that one bank will grant a firm founder's financial request. The 
elasticity for independent banks per capita is 0.309 and the elasticity for bank branches per capita is 0.366 . The access to financial funds represented by bank branches and independent banks per capita tends indeed to be local since it is the municipal variables that are significant. It is the local bank sector that is important, represented by the municipality; firm founders are not influenced by a higher proportion of independent banks or bank branches in the functional region, supporting previous research (Berger et al. 1999; Kwast, 1999; Collender and Shaffer, 2003). The importance of proximity between banks and the customers, on the Norwegian market, is emphasized in the thesis by Dobloug (2012).

The dummy indicating the presence of savings banks in the municipality is insignificant. The same tendency was found in the correlation matrix where the bivariate correlation between the dependent variable and the dummy was insignificant. This was unexpected since savings banks have a profound local agenda and are most often active in the regional development. The same result is identified using the number of bank branches instead of the dummy. The insignificant result might be driven by the homogenous bank structure. Savings banks act and behave as commercial banks and many of them are affiliated with one of the four largest banks in Sweden: Swedbank. Thus, separating out savings banks does not indicate specific characteristics of the bank structure.

As the competition level increases at the municipal level, proxied by the concentration level, new firm formation increases. The empirical findings in this paper support the strand of literature claiming that decreased market power in the banking sector increases the rate of start-ups (Black and Strahan, 2002; Cetorelli, 2003; Cetorelli and Strahan, 2006). Thus, the dual approach in the theory cannot be found in the empirical findings. As the competition level is raised, the supply of financial funds is increased. This is beneficial for the rate of new firm formation since new firms often rely on external finance. As a robustness test, the same estimations have been performed using an ecological approach, i.e. dividing the rate of new firm formation by the number of firms in a municipality, confirming these findings.

Thus, the local bank sector is of importance for the creation of beneficial conditions for new firm formation. ${ }^{\text {ix }}$ The size of the bank branches, the number of places where a firm founder can access financial funds, and increased competition are positively associated with new firm formation while the presence of 
savings banks has an insignificant impact. Even though new technology tends to reduce the importance of physical distance, it still matters in the search for external finance for new firm formation (Petersen and Rajan, 2002).

\section{I.I Control variables: full sample}

The intensity of human capital has a positive impact on new firm formation for the whole sample, which is consistent with previous studies (Johansson and Wigren, 1996; Malmberg, et al., 1996; Malmberg and Maskell, 1997; Parker, 2004; Karlsson and Backman, 2011). A higher proportion of highly educated individuals increase the access to embodied and disembodied knowledge, which increases the rate of start-ups. These individuals can also be used as valuable inputs in the new firm.

The finding that large firms tend to diminish the rate of new firm formation since they function as an entry barrier is supported in this paper. In addition, by working in a small firm, an employee has closer contacts to customers, suppliers, and other parties, which makes it easier for an individual to start his or her own firm (Mason, 1991; Fritsch, 1992; Boden, 1996). Firm density, the number of firms as a share of the municipal population, is significant and positive indicating the importance of knowledge spillovers and proximity to other firms. An alternative interpretation is a higher competition level that according to Porter (1990) is beneficial for innovation and information flows.

In order for a firm formation process to start, firm founders need to have an expected positive profit. If the firm does not target an international market, it will heavily depend on demand from the nearest environment. Change in local demand is in this paper measured as the annual change in the population. If this demand change is sufficiently large, the probability of firm formation will be higher. As expected, an increase in the change in demand has a positive effect on start-ups. These findings agree with those of others (Reynolds et al., 1994; Armington and Acs, 2002; van Stel and Suddle, 2008).

The unemployment rate is insignificant. Thus, the new firm formation rate is not influenced by the fact that many individuals are unemployed; they are neither pushed nor pulled by the occurrence of unemployment into starting a new firm. Similar results are found in Armington and Acs (2002), Reynolds et al. (1994), and Geroski (1995). That government support to new firm formation should be significant and positive is 
intuitively reasonable. The variable is, however, insignificant for the whole sample supporting earlier results by Falkenhall et al. (2003). In the next step, the importance of the local bank sector is examined in different regional settings.

\subsection{Local bank sector: Urban and Rural distinction}

The sample is divided across an urban-rural hierarchy. Due to the limited number of observations, the whole sample is divided into one urban and one rural classification. Urban municipalities are those in the metropolitan functional regions (Stockholm, Gothenburg, and Malmö) as well as the central municipalities in the remaining functional regions. Rural municipalities are hence peripheral municipalities.

The rate of start-ups does not differ considerably across the two categories. The average size of bank branches is roughly twice as large in the urban category and the absolute number of bank branches and independent banks is larger in this category. The reverse picture is found considering the proportion of independent banks and bank branches in relation to the population at the municipal level. At the functional regional level, the proportion of independent banks and bank branches is larger in the urban category. More municipalities in the rural category have savings banks. The competition level is higher in the urban category irrespectively of whether it is measured at the municipal or the functional regional level. The results from estimating Equation 2 for the urban and the rural category are presented in Table 5. 
Table 5 New firm formations and its relationship with the local bank sector separated into an urban and a rural setting, $2 S L S$

\begin{tabular}{|c|c|c|c|c|}
\hline \multicolumn{5}{|l|}{ Dependent variable: Proportion of new firm formation (ln) } \\
\hline & Spec. 1 & Spec. 1 & Spec. 2 & Spec. 2 \\
\hline & Urban & Rural & Urban & Rural \\
\hline Average bank branch employment, municipal level (ln) & $\begin{array}{l}0.075 \\
(0.053)\end{array}$ & $\begin{array}{l}0.220 \\
(0.242)\end{array}$ & $\begin{array}{l}0.082 \\
(0.065)\end{array}$ & $\begin{array}{l}0.236 \\
(0.138)\end{array}$ \\
\hline Individual banks per capita, municipal level (ln) & $\begin{array}{l}0.183^{* *} \\
(0.060)\end{array}$ & $\begin{array}{l}0.558^{*} \\
(0.258)\end{array}$ & - & - \\
\hline Bank branches per capita, municipal level (ln) & - & - & $\begin{array}{l}0.316^{* *} \\
(0.087)\end{array}$ & $\begin{array}{l}0.451 * * \\
(0.111)\end{array}$ \\
\hline $\begin{array}{l}\text { Dummy indicating presence of savings bank, } 1=\text { presence, } \\
0=\text { otherwise, municipal level }\end{array}$ & $\begin{array}{l}-0.188^{* *} \\
(0.070)\end{array}$ & $\begin{array}{l}-0.175 \\
(0.236)\end{array}$ & $\begin{array}{l}-0.197^{*} \\
(0.083)\end{array}$ & $\begin{array}{l}-0.189 \\
(0.173)\end{array}$ \\
\hline $\begin{array}{l}\text { Inverse Herfindahl-Hirschman index, based on number of } \\
\text { employees, municipal level (ln) }\end{array}$ & $\begin{array}{l}0.098 \\
(0.08)\end{array}$ & $\begin{array}{l}0.298^{*} \\
(0.151)\end{array}$ & $\begin{array}{l}-0.021 \\
(0.075)\end{array}$ & $\begin{array}{l}-0.029 \\
(0.081)\end{array}$ \\
\hline Individual banks per capita, functional region (ln) & - & - & $\begin{array}{l}-0.095 \\
(0.077)\end{array}$ & $\begin{array}{l}-0.051 \\
(0.133)\end{array}$ \\
\hline Bank branches per capita, functional region (ln) & $\begin{array}{l}0.122 \\
(0.182)\end{array}$ & $\begin{array}{l}-0.450 \\
(0.272)\end{array}$ & - & - \\
\hline $\begin{array}{l}\text { Inverse Herfindahl-Hirschman index, based on number of } \\
\text { employees, functional region (ln) }\end{array}$ & $\begin{array}{l}0.035 \\
(0.029)\end{array}$ & $\begin{array}{l}0.060 \\
(0.063)\end{array}$ & $\begin{array}{l}0.057 \\
(0.037)\end{array}$ & $\begin{array}{l}0.005 \\
(0.042)\end{array}$ \\
\hline $\begin{array}{l}\text { Proportion of labor force with three or more years of higher } \\
\text { education, municipal level (ln) }\end{array}$ & $\begin{array}{l}0.431 * * \\
(0.072)\end{array}$ & $\begin{array}{l}0.198 \\
(0.199)\end{array}$ & $\begin{array}{l}0.397 * * \\
(0.067)\end{array}$ & $\begin{array}{l}0.295^{*} \\
(0.117)\end{array}$ \\
\hline Mean establishment size, municipal level (ln) & $\begin{array}{l}-0.890^{* *} \\
(0.086)\end{array}$ & $\begin{array}{l}-0.552^{* *} \\
(0.146)\end{array}$ & $\begin{array}{l}-0.811^{* *} \\
(0.090)\end{array}$ & $\begin{array}{l}-0.585^{* *} \\
(0.091)\end{array}$ \\
\hline Number of firms divided by the population, municipal level (ln) & $\begin{array}{l}0.424^{* *} \\
(0.192)\end{array}$ & $\begin{array}{l}0.699 * * \\
(0.365)\end{array}$ & $\begin{array}{l}0.702^{* *} \\
(0.194)\end{array}$ & $\begin{array}{l}0.768 \\
(0.528)\end{array}$ \\
\hline Change in population from 2009 to 2010 , municipal level & $0.012 *$ & -0.105 & 0.007 & -0.094 \\
\hline
\end{tabular}




\begin{tabular}{l|c|c|c|c} 
& $(0.009)$ & $(177)$ & $(0.020)$ & $(0.129)$ \\
\hline Unemployment rate, municipal level (ln) & 0.112 & -0.046 & 0.084 & 0.005 \\
& $(0.065)$ & $(0.110)$ & $(0.072)$ & $(0.084)$ \\
\hline Average monthly number of state subsidies to start-ups, municipal & 0.009 & -0.013 & -0.008 & -0.006 \\
level (ln) & $(0.017)$ & $(0.032)$ & $(0.020)$ & $(0.022)$ \\
\hline Constant & 1.526 & 0.142 & 0.890 & 1.503 \\
& $(0.943)$ & $(1.324)$ & $(0.816)$ & $(0.828)$ \\
\hline $\mathrm{N}$ (municipalities) & 139 & 151 & 139 & 151 \\
\hline $\mathrm{R}^{2}$ & 0.63 & 0.53 & 0.63 & 0.53 \\
\hline
\end{tabular}

Robust standard errors in parentheses, ${ }^{* *}$ significant at one percent, ${ }^{*}$ significant at five percent. The variables describing the local bank sector is instrumented with the same variables in 1995 and the number of savings banks in each municipality in 1895.

The number of observations is low compared to the number of independent variables leading to a low degree of freedom. To check the robustness of the results for the variables used to describe the local bank sector, estimations with only these variables were performed and confirm the results in Table 5, these results can be requested from the author.

The average size of a bank branch is not significant in the urban or in the rural category. More independent banks and bank branches per capita at the municipal level is significant and positive for both categories. The elasticities are, however, higher in rural municipalities. The difference is statistical significant. The finding that banks are more important for rural locations in Sweden has been identified by Berggren and Silver (2010). This result might be driven by the alternative financing options that exist in more urban settings. Venture capital and business angels only contribute to a small share of the total financing of new firms in Sweden. Even so, venture capital is heavily concentrated in the two largest metropolitan regions in Sweden, Stockholm and Gothenburg (SVCA, 2008). Thus, in these municipalities venture capital might be an option for external financing. Another factor could be the industrial structure in the different categories. Banks might be of less importance in urban areas since most of the start-ups are concentrated in the service sector where 
the need for external finance is limited or non-existent. The same variables are not significant at the functional region level.

The presence of savings banks indicated by the dummy is not significant for the rural category while it is negative for the urban category. That the presence of savings banks is negatively associated with new firm formation in this category can be explained by the fact that savings banks establish in all locations and not only in prosperous ones. The presence of savings banks is not per se a negative thing but signals a location with less beneficial conditions that negatively influence the rate of start-ups. The competition level is only significant for rural municipalities, measured at the municipal level. Hence, locations with an average lower competition level, based on the descriptive statistics, benefit from increasing the competition level. Urban locations might already have a high level of competition and are therefore less sensitive to a marginal increase in the competition level.

\subsection{Control variables: Urban and Rural distinction}

All control variable show the same influence for both the urban and rural category, except the demand variable which is only significant in the case of urban municipalities. Government support to new firm formation and the municipal unemployment rate is insignificant both in the rural and urban settings. Human capital intensity, mean establishment size and industry structure are significant in both categories and of the same sign and size.

\section{Conclusions}

The bank sector in Sweden is dominated by four major banks with local bank branches all over the country. Studies have found that potential firm founders in some municipalities are hindered by low or no access to financial funds. This paper analyses how the characteristics of the local bank sector influences new firm formation in Swedish municipalities. This paper provides support for the importance of the structure of the local bank sector for new firm formation. The findings show a positive relationship between the average size of the bank branches, independent banks per capita, bank branches per capita, and the number of local start- 
ups in Sweden. Hence, access to financial funds is important for new firm formation. There is no consensus in the theoretical approach about the effect of competition in the banking sector on business creation. There is, however, an empirical coherence in this paper that competition (decreased concentration) is positively associated with the rate of new firms. When the sample is divided into one urban and one rural category, differences arise concerning the importance of the local bank sector. Independent banks per capita and bank branches per capita are significant and positive for both categories. The value of the elasticity is, however, higher in rural municipalities. These findings accentuate the importance of banks for new firm formation in these municipalities since other financial sources such as venture capital are concentrated in metropolitan regions. The competition variable is only significant (and positive) in the case of rural municipalities.

Access to financial funds is one factor that facilitates the creation of new firms and partly depends on the structure of the local bank sector. Intervention by the government to broaden access to financial services is often costly and associated with the risk that the groups most in need of increased access to financial funds will not be affected by the policy. One option is to assist potential firm founders with education and knowledge about how to develop business proposals and business plans so that these become more transparent for banks in case of a loan request. The finding that the proportion of independent banks and the level of competition increase new firm formation supports the policy of opening up the Swedish bank market to foreign actors. In addition, mergers that reduce local competition could be harmful since they can reduce the supply of financial resources. This is especially important in rural areas where the dependence on banks for new firm formation tends to be larger. Even though many bank services are available online and therefore not sensitive to where the bank or its customer is located, the procedure of accessing financial funds for a new firm requires personal meetings. This indicates that closing down bank branches in municipalities reduces the access to external funds for the type of bank services associated with a loan request for a start-up. Bank branch closures are often more prevalent in rural areas and may reduce the access to financial funds for potential firm founders in that location.

This study is based on Swedish data, and even though the Swedish institutional setting is rather unique, the results are most likely applicable in other developed countries that are heavily dependent on banks, such as 
Germany and Japan. To deepen the understanding of how loan providers influence new firm formation, municipal structure, i.e. rural and urban areas, can be combined with different industries. The urban and rural hierarchy can be extended to allow for more variation in the regional categories. By including the time dimension, the causality issue could be examined. In addition, possible effects from the institutional changes that occurred in Sweden during the 1990s could be identified. 
i Venture capital and loans from the public sector only constitute a small fraction of total financing compared to bank lending (Berggren et al., 2001; Berger and Udell, 2002). Only one to three percent of all start-ups are financed through venture capital (Parker, 2004).

ii The correlation between the entry rate and cost of a business start-up (based on data from the World Bank) among 173 countries is 0.25 . The correlation among middle-and high-income countries is -0.35 .

iii It is the overall level of financial and legal development that matters for start-ups. A bank-based system is no better or worse than a market-based system in fostering firm formation (Beck and Levine, 2000).

iv Sweden is classified as having an intermediary-based system when the definition of financial intermediaries includes firms that are not classified as banks, although they supply bank-like financial services.

v For confidentiality reasons the number of employees is not reported as a continuous variable but instead according to different employment size classes: 1-4, 5-9, 10-19, 20-49, 50-99, 100-199, 200-499, 500-999, 1000-1499, 1500-1999, and 2000-2999.

vi An earlier version of this paper used a GMM approach on the period 1997-2007. The data on the local bank sector were not as detailed; the only variables included were bank branches per capita and average size of each bank branch. The results were similar to the findings in this paper.

vii Similar results are found using a Limited Information Maximum Likelihood (LIML) model.

viii Spatial dependence is tested using the Moran's I measure and is not significant at the one percent level for either spatial error or spatial lag. The p-value for the spatial error is, however, low: a spatial error model is therefore tested and significance and magnitude are the same. During 2010, the financial requirement for starting a joint-stock firm was lowered from 100000 SEK to 50000 SEK. In order to test if this institutional change affected the results in this paper, the same estimations were performed for 2005 with similar results.

ix The result is robust for firm sizes (i) 1-4 employees, and (ii) above 4 employees. The parameters are not significantly different from each other when the different size cohorts are compared. Thus, the local bank market is important irrespective of the size of the startup. 


\section{References}

Akerlof, G. A. (1970). The Markets for "Lemons": Quality Uncertainty and the Market Mechanism. Quarterly Journal of Economics, 84(3), 488-500.

Andersson, A. E., Andersson, D. E., and Holmberg, I. (2001). Grogrund för tillväxt: Östra Skänes utveckling. Malmö: Grafix Konsult AB.

Armington, C., and Acs, Z. J. (2002). The Determinants of Regional Variation in New Firm Formation. Regional Studies, 36(1), 33 - 45.

Ashcroft, B., Love, J. H., and Malloy, E. (1991). New Firm Formation in the British Counties with Special Reference to Scotland. Regional Studies, 25(5), 395-409.

Audretsch, D. B., Carree, M. A., and Thurik, A. R. (2001). Does Entrepreneurship Reduce Unemployment?, Tinbergen Institute Discussion Paper Series TI 2001-074/3, available at http://hdl.handle.net/1765/6857

Audretsch, D. B., and Fritsch, M. (1994). On the Measurement of Entry Rates. Empirica, 21 (1), 105-113.

Beck, T., Demirguc-Kunt, A., Laeven, L., and Levine, R. (2008). Finance, Firm Size, and Growth. Journal of Money, Credit and Banking, 40(7), 1379-1405.

Beck, T., Demirguc-Kunt, A., and Maksimovic, V. (2004). Bank Competition and Access to Finance: International Evidence. Journal of Money, Credit, and Banking 36(3), 627-648.

Beck, T., and Levine, R. (2000). New Firm Formation and Industry Growth. Does Having a Market- or BankBased System Matter?: Policy Research Working Paper Series No. 2383. Washington, DC: The World Bank.

Berger, A. N., Demsetz, R. S., and Strahan, P. E. (1999). The consolidation of the financial services industry: Causes, consequences, and implications for the future. Journal of Banking \& Finance, 23(2-4), 135-194.

Berger, A. N., and Udell, G. F. (2002). Small business credit availability and relationship lending: the importance of bank organisational structure. Economic Journal, 112(477), F32-F53. 
Berggren, B., Lindström, G., and Olofsson, C. (2001). Tillväxt och finansiering i mindre företag [in Swedish]. In P. Davidsson, F. Delmar, and J. Wiklund (Eds.), Tillväxtföretagen i Sverige (pp. 250-271). Stockholm: SNS Förlag.

Berggren, B., and Silver, L. (2010). Financing entrepreneurship in different regions: The failure to decentralise financing to regional centres in Sweden. Journal of Small Business and Enterprise Development, 17(2), 230246.

Binks, M., and Jennings, A. (1986). Small firms as a source of economic rejuvenation. In J. Curran, J. Stanworth and D. Watkins (Eds.), The Survival of the Small FirmVol. 1: The Economics of Survival and Entrepreneurship (pp. 19-37). Aldershot, UK: Gower.

Black, S. E., and Strahan, P. E. (2002). Entrepreneurship and Bank Credit Availability. Journal of Finance, 57(6), 2807-2833.

Blanchflower, D. G., Oswald, A., and Stutzer, A. (2001). Latent entrepreneurship across nations. European Economic Review, 45(4-6), 680-691.

Boden Jr., R. J. (1996). Gender and self-employment selection: An empirical assessment. Journal of SocioEconomics, 25(6), 671-682.

Bolton, P., and Dewatripont, M. (1994). The Firm as a Communication Network. Quarterly Journal of Economics, 109(4), 809-839.

Bonaccorsi di Patti, E., and Dell'Ariccia, G. (2004). Bank Competition and Firm Creation. Journal of Money, Credit and Banking, 36(2), 225-251.

Bosma, N., Jones, K., Autio, E., and Levie, J. (2007). Global Entrepreneurship Monitor: 2007 Exexutive report. Babson Park, MA: Babson College and London, UK: London Business School.

Bygrave, W. D. (1988). The structure of the investment networks of venture capital firms. Journal of Business Venturing, 3(2), 137-157.

Cameron, A. C., and Trivedi, P. K. (2009). Microeconomics Using STATA. Revised Edition. Texas: Stata Press.

Cantillon, R. (1755). Essai sur la Nature du Commerce en Général. Tokyo: Kinokuniya bookstore Co.

Cassar, G. (2004). The financing of business start-ups. Journal of Business Venturing, 19(2), 261-283. 
Cestone, G., and White, L. (2003). Anticompetitive Financial Contracting: The Design of Financial Claims. Journal of Finance, 58(5), 2109-2142.

Cetorelli, N. (2003). Life-Cycle Dynamics in Industrial Sectors: The Role of Banking Market Structure. Quarterly Review, Federal Reserve Bank of St.Louis, 85, 135-148.

Cetorelli, N. (2004). Real Effects of Bank Competition. Working Paper Series No. WP-04-03. Chicago, IL: Federal Reserve Bank of Chicago.

Cetorelli, N., and Strahan, P. E. (2006). Finance as a Barrier to Entry: Bank Competition and Industry Structure in Local U.S. Markets. Journal of Finance, 61(1), 437-461.

Ciccone, A., and Hall, R. E. (1996). Productivity and the Density of Economic Activity. American Economic Review, 86(1), 54-70.

Collender, R. N., and Shaffer, S. (2003). Local bank office ownership, deposit control, market structure, and economic growth. Journal of Banking \& Finance, 27(1), 27-57.

Colombo, M. G., and Grilli, L. (2006). Funding Gaps? Access To Bank Loans By High-Tech Start-Ups Small Business Economics, 29(1-2), 25-46.

Combes, P.-P., Duranton, G., Gobillon, L., and Roux, S. (2010). Estimating Agglomeration Economies with History, Geology, and Worker Effects. In E. L. Glaeser (Ed.), Agglomeration Economics (pp. 15-66). Chicago: University of Chicago Press.

Davidsson, P., Lindmark, L., and Olofsson, C. (1994). New Firm Formation and Regional Development in Sweden. Regional Studies, 28(4), 395-410.

Davis, S. J., and Henrekson, M. (1997). Industrial Policy, Employer Size, and Economic Performance in Sweden. In R. B. Freeman, R. Topel and B. Swedenborg (Eds.), The Welfare State in Transition: Reforming the Swedish Model (pp. 353-398). Chicago, IL: University of Chicago Press.

Dell'Ariccia, G., and Marquez, R. (2004). Information and bank credit allocation. Journal of Financial Economics, 72(1), 185-214.

Demirguc-Kunt, A., and Levine, R. (2004). Financial Structure and Economic Growth. A Cross-Country Comparison of Banks, Markets, and Development. Cambridge, MA: MIT Press. 
Dinc, I.S. (2000). Bank reputation, bank commitment, and the effects of competition in credit markets. Review of Financial Studies, 13(3), 781-812.

Dobloug, T. A. (2012). Hoyvelestbedrifter og regionale finansieringssystemer [in Norwegian]. Ph.D. Dissertation, Lund Universitet, Lund.

Duranton, G., and Puga, D. (2004). Micro-foundations of urban agglomeration economies. In J. V. Henderson and J.-F. Thisse (Eds.), Handbook of Regional and Urban Economics (Vol. Volume 4, pp. 20632117). Amsterdam: Elsevier.

Evans, D. S., and Jovanovic, B. (1989). An Estimated Model of Entrepreneurial Choice under Liquidity Constraints. Journal of Political Economy, 97(4), 808-827.

Falkenhall, B., Johansson, M., and Olofsson, J. (2003). Utvärdering av de näringspolitiska effekterna av stöd till start av näringsverksamhet [in Swedish]. Östersund: ITPS, Institutet för tillväxtpolitiska studier, A2003:003.

Feldman, M., Francis, J., and Bercovitz, J. (2005). Creating a Cluster While Building a Firm: Entrepreneurs and the Formation of Industrial Clusters. Regional Studies, 39(1), 129-141.

Florida, R. L., and Kenney, M. (1988). Venture Capital, High Technology and Regional Development. Regional Studies, 22(1), 33-48.

Francois, J. F. (1990). Producer Services, Scale, and the Division of Labor. Oxford Economic Papers, 42(4), 715729.

Fritsch, M. (1992). Regional Differences in New Firm Formation: Evidence from West Germany. Regional Studies, 26(3), 233-241.

Fritsch, M., and Schilder, D. (2008). Does venture capital investment really require spatial proximity? An empirical investigation. Environment and Planning A, 40 (9), 2114-2131.

Gereffi, G., Humphrey, J., and Sturgeon, T. (2005). The governance of global value chains. Review of International Political Economy, 12(1), 78-104.

Geroski, P. A. (1995). What do we know about entry? International Journal of Industrial Organization, 13(4), 421440. 
Handelsbanken. (2008). 2008 Arsöversikt [in Swedish]. Stockholm: Svenska Handelsbanken AB.

Hayek, F. A. (1945). The Use of Knowledge in Society. American Economic Review, 35(4), 519-530.

Henrekson, M. (2005). Entrepreneurship: a weak link in the welfare state? Industrial and Corporate Change, 14(3), 437-467.

Johansson, B., Klaesson, J., and Olsson, M. (2003). Commuters' non-linear response to time distances. Journal of Geographical Systems, 5(3), 315-329.

Johansson, B., and Wigren, R. (1996). Production Milieu and Competitive Advantages. In D.F. Batten and C. Karlsson (Eds.), Infrastructure and the Complexity of Economic Development (pp. 187-212). Berlin: SpringerVerlag.

Karlsson, C., and Backman, M. (2011). Accessibility to human capital and new firm formation. International Journal of Foresight and Innovation Policy, 7 (1/2/3), 7-22.

Keeble, D. E. (1989). High-technology industry and regional development in Britain: the case of the Cambridge phenomenon. Environment and Planning C, 7(2), 153-172.

King, R. G., and Levine, R. (1993a). Finance and Growth: Schumpeter Might Be Right. Quarterly Journal of Economics, 108(3), 717-737.

King, R. G., and Levine, R. (1993b). Finance, entrepreneurship and growth: Theory and evidence. Journal of Monetary Economics, 32(3), 513-542.

Kirzner, I. M. (1973). Competition and Entrepreneurship. Chicago, IL: University of Chicago Press.

Knight, F. H. (1921). Risk, Uncertainty, and Profit. New York, NY: Houghton Mifflin.

Kwast, M. L. (1999). Bank mergers: What should policymakers do? Journal of Banking \& Finance, 23(2-4), 629636.

Leinbach, T. R., and Amrhein, C. (1987). A Geography of the Venture capital Industry in the U. S. The Professional Geographer, 39(2), 146-158.

Levine, R. (1997). Financial Development and Economic Growth: Views and Agenda. Journal of Economic Literature, 35(2), 688-726.

Lieberson, S. (1961). The Division of Labor in Banking. American Journal of Sociology, 66(5), 491-496. 
Malmberg, A., and Maskell, P. (1997). Towards an explanation of regional specialization and industry agglomeration. European Planning Studies, 5(1), 25-41.

Malmberg, A., Sölvell, Ö., and Zander, I. (1996). Spatial Clustering, Local Accumulation of Knowledge and Firm Competitiveness. Geografiska Annaler, Series B, Human Geography, 78(2), 85-97.

Marshall, A. (1890). Principles of Economics: An Introductory Volume. London, UK: Macmillan.

Martin, P., Mayer, T., and Mayneris, F. (2011). Spatial concentration and plant-level productivity in France. Journal of Urban Economics, 69(2), 182-195.

Mason, C. (1991). Spatial variations in enterprise: the geography of new firm formation. In R. Burrows (Ed.), Deciphering the Enterprise Culture: Entrepreneurship, petty Capitalism and the Restructuring of Britain (pp. 74106). New York, NY: Routledge.

McQuaid, R. W. (2002). Entrepreneurship and ICT Industries: Support from Regional and Local Policies. Regional Studies, 36(8), 909-919.

Michelacci, C., and Silva, O. (2007). Why So Many Local Entrepreneurs? Review of Economics and Statistics, 89(4), 615-633.

Mueller, E., and Morgan, J. N. (1962). Location Decisions of Manufacturers. American Economic Review, 52(2), 204-217.

Murray, G. C. (1998). A Policy Response to Regional Disparities in the Supply of Risk Capital to New Technology-based Firms in the European Union: The European Seed Capital Fund Scheme. Regional Studies, 32(5), 405-419.

Nykvist, J. (2008). Entrepreneurship and Liquidity Constraints: Evidence from Sweden. Scandinavian Journal of Economics, 110(1), 23-43.

Nyström, K. (2006). Entry and Exit in Swedish Industrial Sectors., JIBS Dissertation Series, No 032. Jönköping: Jönköping International Business School.

Ongena, S., and Smith, D. C. (2000). What Determines the Number of Bank Relationships? Cross-Country Evidence. Journal of Financial Intermediation, 9(1), 26-56. 
Pagano, P., and Schivardi, F. (2003). Firm Size Distribution and Growth. Scandinavian Journal of Economics, 105(2), 255-274.

Parker, S. C. (2004). The Economics of Self-Employment and Entrepreneurship. Cambridge, UK: Cambridge University Press.

Petersen, M. A., and Rajan, R. G. (1995). The Effect of Credit Market Competition on Lending Relationships. Quarterly Journal of Economics, 110(2), 407-443.

Petersen, M. A., and Rajan, R. G. (2002). Does Distance Still Matter? The Information Revolution in Small Business Lending. Journal of Finance, 57(6), 2533-2570.

Pollard, J. S. (2003). Small firm finance and economic geography. Journal of Economic Geography, 3(4), 429-452.

Porter, M. E. (1990). The Competitive Advantage of Nations. London, UK: Macmillan.

Rajan, R. G., and Zingales, L. (1998). Financial Dependence and Growth. American Economic Review, 88(3), 559586.

Renski, H.C. (2008). New Firm Entry, Survival, and Growth in the United States: A Comparison of Urban, Suburban, and Rural Areas. Journal of the American Planning Association, 75(1), 60-77.

Reynolds, P., Storey, D. J., and Westhead, P. (1994). Cross-national Comparisons of the Variation in New Firm Formation Rates. Regional Studies, 28 (4), 443-456.

Robinson, J. (1952). The Generalization of the General Theory. In J. Robinson, The Rate of Interest, and Other Essays (pp. 67-142). London, UK: Macmillan.

Say, J.-B. (1803). A Treatise on Political Economy or the Production, Distribution and Consumption of Wealth. New York, NY: A.M. Kelley Publishers.

Schumpeter, J. A. (1934). The Theory of Economic Development: An Inquiry into Profits, capital, Credit, Interest, and the Business Cycle. Cambridge, MA: Harvard University Press.

Sjögren, H., and Zackrisson, M. (2005). The Search for Competent Capital: Financing of High Technology Small Firms in Sweden and USA. Venture Capital: An International Journal of Entrepreneurial Finance, 7(1), 75-97. 
Smith, A. (2001 [1776] ). An Inquiry into the Nature and Causes of the Wealth of Nations. London, UK: The Adam Smith Institute.

Sorenson, O., and Audia, P. G. (2000). The Social Structure of Entrepreneurial Activity: Geographic Concentration of Footwear Production in the United States, 1940-1948. American Journal of Sociology, 106(2), 424-462.

Spagnolo, G. (2000). Debt as a (Credible) Collusive Device: SSE Working Paper No. 349 - FEEM Working Paper No.94.99.

Stigler, G. J. (1951). The Division of Labor is Limited by the Extent of the Market. Journal of Political Economy, 59(3), 185-193.

Stiglitz, J. E., and Weiss, A. (1981). Credit Rationing in Markets with Imperfect Information. The American Economic Review, 71(3), 393-410.

Storey, D. J. (1994). New firm growth and bank financing. Small Business Economics, 6(2), 139-150.

Storey, D. J., and Wynarczyk, P. (1996). The survival and non survival of micro firms in the UK. Review of Industrial Organization, 11(2), 211-229.

Storper, M., and Venables, A. J. (2004). Buzz: face-to-face contact and the urban economy. Journal of Economic Geography, 4(4), 351-370.

Sutaria, V., and Hicks, D. A. (2004). New firm formation: Dynamics and determinants. Annals of Regional Science, 38(2), 241-262.

SVCA. (2008). Swedish Private Equity \& Venture Capital Association. Stockholm: SVCA.

Svenska Bankföreningen. (2010). Banker i Sverige: Faktablad om svensk bankmarknad [in Swedish]. Stockholm: Svenska Bankföreningen.

Thakor, A. V. (1996). Capital Requirements, Monetary Policy, and Aggregate Bank Lending: Theory and Empirical Evidence. Journal of Finance, 51(1), 279-324.

Tucker, M. (2006). Access to Finance in Europe. Local Economy, 21(1), 78-83.

van Praag, C. M., and Versloot, P.H. (2007). What is the value of entrepreneurship? A review of recent research. Small Business Economics, 29(4), 351-382. 
van Stel, A., and Suddle, K. (2008). The impact of new firm formation on regional development in the Netherlands. Small Business Economics, 30(1), 31-47.

Winker, P. (1999). Causes and Effects of Financing Constraints at the Firm Level. Small Business Economics, 12(2), 169-181. 